\title{
Şırnak ili pamuk ekim alanlarında bulunan zararlı lepidoptera türleri, popülasyon yoğunlukları ve avcıları üzerinde araştırmalar
}

Research on lepidopteran pests, their population densities and predatory insects in cotton production areas in Şırnak Province, Turkey

\section{Tarkan AYAZ ${ }^{1}$ (D), Feza CAN ${ }^{2}$ (i)}

${ }^{1}$ Şırnak Üniversitesi, Ziraat Fakültesi, Bitki Koruma Bölümü, Idil, Şırnak.

${ }^{2}$ Hatay Mustafa Kemal Üniversitesi, Ziraat Fakültesi, Bitki Koruma Bölümü, Antakya, Hatay.

\section{MAKALE BILGISI / ARTICLE INFO}

\section{Makale tarihçesi / Article history:}

DOI: $10.37908 /$ mkutbd.885475

Geliş tarihi /Received:23.02.2021

Kabul tarihi/Accepted:24.05.2021

\section{Keywords:}

Şırnak, cotton, pest, lepidoptera, population.

\footnotetext{
Corresponding author: Tarkan AYAZ

凶: tarkanayaz@gmail.com
}

\section{ÖZET / ABSTRACT}

\footnotetext{
Atıf / Citation: Ayaz T, Can F (2021) Şırnak ili pamuk ekim alanlarında bulunan zararlı lepidoptera türleri, popülasyon
yoğunlukları ve avcıları üzerinde araştırmalar. MKU. Tar. Bil. Derg. 26(3) : 516-532. DOI:

Atıf / Citation: Ayaz T, Can F (2021) Şırnak ili pamuk ekim alanlarında bulunan zararlı lepidoptera türleri, popülasyon
yoğunlukları ve avcıları üzerinde araştırmalar. MKU. Tar. Bil. Derg. 26(3) : 516-532. DOI: 10.37908/mkutbd. 885475
} 


\section{Giriş}

Pamuk, insan yaşamında kullanım yeri oldukça geniş olması nedeniyle dünyada tarımı ve ticareti en başta gelen ürünlerdendir. Pamuk lifleri özellikle tekstilde hammadde olarak kullanılırken, tohumlarındaki yă̆ oranının yüksekliğinden dolayı dünya yağ ihtiyacını karşılamada da önemli rol oynamaktadır. Türkiye pamuk üretiminde Hindistan, Çin, ABD, Brezilya ve Pakistan'dan sonra 6. sırada, verimde ise Avustralya, Çin, Brezilya, ve Meksika'nın ardından 5. sırada yer almaktadır (Anonim, 2019). Pamuğun öneminin artması ile pamuk alanlarında bulunan zararlı böcek türleri de önem kazanmaya başlamıştır. Pamuk alanlarında zarar meydana getiren böceklerin başında Lepidoptera takımına bağlı türler gelmektedir. Pamukta zararlı Lepidoptera türlerinin dünyada ve ülkemizdeki durumu ve önemini ortaya koyabilmek için çok sayıda çalışma yapılmıştır. Wilson ve ark. (1979) ABD'de pembekurt, Klein ve ark. (1981) İsrail'de dikenlikurt, Abul-Nasr ve ark. (1983) Mısır'da pembekurt ve dikenlikurt, El Mosa (1986) ise Suriye'de dikenlikurt ile yapmış oldukları çalışmalar lepidopterlerin dünya pamuk alanlarındaki durumunu ortaya koyan çalışmalardan başlıcalarıdır. Ülkemizde ise Kıray'ın (1964) Çukurova'da dikenli kurdun dört ırkının olduğunu ve bunların morfolojik özelliklerini belirttiği çalışma, Karman'ın (1960) Ege Bölgesinde pembe kurdun zararını ortaya koyduğu çalışma, Yabaş'ın (1979) Çukurova'da ve Göven'in (1995) Güneydoğu Anadolu Bölgesinde yeşil kurdun zararı ve Eren'in (2006) Güneydoğu Anadolu Bölgesinde dikenli kurdun durumu ile ilgili yapmış oldukları çalışmalar Lepidopter türlerinin Türkiye'deki pamuk alanlarındaki önemini ortaya koyan ilk çalışmalardır. Zararlı olan böceklerin başında Lepidoptera takımına giren türler gelmektedir. Lepidoptera takımına ait bazı türler pamuk ekim alanlarında önemli zarar oluşturarak büyük verim kayıplarına neden olabilmektedirler (Lodos, 1981; Göven, 1995 ve Eren, 2006).

Şırnak ilindeki pamuk alanlarında yapılan gözlemlerde Lepidoptera türlerinin yoğun olarak zarar yaptığı ve çiftçilerin bilinçsizce yoğun bir şekilde ilaçlama yaptıkları görülmüştür. Bu çalışma, Şırnak ili Cizre ve Silopi ilçelerinde pamuk alanlarındaki zararlı Lepidopter türlerini, önemli türlerin popülasyon gelişimlerini ve doğal düşmanlarını belirlemek amacıyla yapılmıştır.

\section{MATERYAL ve YÖNTEM}

\section{Şırnak ili pamuk ekim alanlarında zararlı lepidoptera türlerinin belirlenmesi}

Çalışma, Lepidoptera takımına bağıı zararlı türleri belirleyebilmek amacıyla pamuğun ekiminden hasada kadar haftada bir kez arazi çıkışı ile birbirine en az $5 \mathrm{~km}$ mesafede olan pamuk tarlalarında örneklemeler yapmak suretiyle yürütülmüştür. Böylece yıl boyu bitkinin tüm fenolojik dönemlerinde gözle kontrol yöntemi ile örneklemeler yapılmıştır. Kontrol edilen tarlalarda köşegenler doğrultusunda yürünerek tesadüfen seçilen toplam 20 bitkinin tüm aksamları gözle incelenerek elde edilen Lepidoptera türlerine ait yumurta, larva ve pupalar ergin elde edebilmek amacıyla etiket bilgileri ile birlikte laboratuvara getirilerek kültüre alınmıştır. Arazi çıkışlarına 2016 yılında 15.04.2016 tarihinde, 2017 yılında ise 21.04.2017 tarihinde başlanmıştır.

\section{Pamuk ekim alanlarında belirlenen lepidoptera türlerinin ergin popülasyon değişimi}

Silopi ve Cizre ilçelerinde yapılan çalışmalarda daha sık rastlanan ve diğer türlere oranla daha yoğun olarak görülen Lepidoptera türlerinin popülasyon değişimlerini incelemek amacıyla 2016-2017 yıllarında ekim alanlarının büyüklüğü göz önünde bulundurularak Silopi ilçesinde iki, Cizre ilçesinde ise bir adet olmak üzere, her iki bitki türü için 100 dekardan büyük, Lepidoptera türlerine karşı ilaç uygulaması yapılmayan ışık tuzakları ve feromon tuzaklarının kurulduğu 3 tarla belirlenmiştir.

Çizelge 1. Çalışmanın yürütüldüğü pamuk tarlalarının koordinat bilgileri

Table 1. Coordinate information of the cotton fields where the study was conducted

\begin{tabular}{lccc}
\hline İlçe-Köy & Tarla & $\mathbf{K}\left({ }^{\circ},{ }^{\prime}, "\right)$ & $\mathbf{D}\left({ }^{\circ},{ }^{\prime}, "\right)$ \\
\hline Silopi-Pınarönü & Tarla-1 & 423472 & 372751 \\
\hline Silopi-Özgen & Tarla-1 & 425282 & 372296 \\
\hline Cizre-İnci & Tarla-1 & 422653 & 372790 \\
\hline
\end{tabular}

Pamuk alanlarında bulunan Lepidoptera türleri genellikle gece aktif türler olduklarından ergin popülasyon değişimlerini belirlemek için ışık tuzakları kullanılmıştır. içcerisinde $550 \mathrm{~g} / \mathrm{l}$ dichlorvos etki maddeli EC formulasyonlu insektisit emdirilmiş talaş bulunan ve 160 Watt'ık civa buharlı ampulle çalışan Robinson tipi ışık tuzakları her tarlaya birer adet kurulmuş ve fotosel sistemi ile günbatımından güneş doğana kadar açık kalacak şekilde ayarlanmıştır. Tuzaklar haftada bir kez kontrol edilerek yakalanan erginlerin sayıları yeşilkurt ve 
dikenlikurt için ayrı ayrı kaydedilmiş ve tuzaktan uzaklaştırılmıştır.

Pamuk alanlarında bulunan yeşilkurt, dikenlikurt ve pembekurt türlerinin yoğunluklarını takip edebilmek için feromon tuzaklar kullanılmıştır. Çalışmada kullanılan Funnel tipi feromon tuzaklar belirlenen tarlalara her bir zararlı için birer adet olmak üzere demir çubuklar sayesinde 1,5 metre yüksekliğe gelecek şekilde kurulmuş ve tuzakların feromonları 45 günde bir düzenli olarak yenileri ile değiştirilmiştir. Alanlara kurulan tuzaklar haftalık olarak kontrol edilmiş, yakalanan bireyler kayıt altına alındıktan sonra ve tuzaktan uzaklaştırılmıştır.

\section{Pamuk ekim alanlarında tespit edilen lepidoptera} türlerinin doğal düşmanlarının belirlenmesi

haftalık olarak yapılan arazi çıkışlarında, Lepidoptera takımına bağlı türlerin doğal düşmanlarını belirlemek için pamuk alanlarında 100'er atrap sallanmış ve elde edilen böcekler emgi şişesi ile alınıp öldürme şişesine aktarılmıştır. Elde edilen örnekler laboratuvara getirilerek tasnif edilmiştir. Pamuk tarlalarında tesadüfen seçilen 50 bitkide yapılan gözle kontrol yönteminde bulunan erginler tarlada sayılmış, elde edilen elde edilen doğal düşman yumurta, larva ve pupalar ise laboratuvara getirilerek kültüre alınmış ve erginleri elde edilmiştir.

\section{Laboratuvar çalışmaları}

Laboratuvara getirilen yumurta, larva ve pupalar bitki materyalleri ile birlikte $26 \pm 1$ OC sıcaklık ve $\% 70 \pm 10$ orantılı nem koşullarını sağlayan iklim odalarında bulunan $50 \times 50 \times 100 \mathrm{~cm}$ ebatlarındaki üst ve ön kısmı cam, diğer tarafları tülle kaplanmış üretim kafesleri içine konularak kültüre alınmıştır. Araziden elde edilen ergin bireyler kurumalarına fırsat verilmeden özel germe tahtalarında kurallara uygun olarak gerilerek oda şartlarında 2-4 hafta kurumaya bırakılarak etiketlenmiştir. Sabit tuzaklardan elde edilen bireyler ise bir kenarında nemli pamuk bulunan cam petrilere konularak 1-2 gün bekletilmiştir. Elde dilen türler gerilip etiketlenerek müze materyali haline getirilmiştir. Lepidoptera takımında dış genital organlar sabit morfolojik karakterleri göstermeleri nedeniyle taksonomik çalışmalarda genital organ yapıları dikkate alınmıştır. Bu amaçla erkek ve dişi genital organ preparatları standart metodlar kullanılarak (Doğanlar, 2003) hazırlanmış ve tür teşhisleri yapılmıştır. Lepidoptera takımına bağlı türlerin teşhis çalışamaları, Hatay Mustafa Kemal Üniversitesi Ziraat Fakültesi Bitki Koruma Bölümü'nden Prof. Dr. Feza CAN tarafından yapılmıştır. Avcı böceklerin teşhis çalışmaları ise Prof. Dr. İnanç ÖZGEN tarafından teşhisli örneklerden faydalanılarak yapılmıştır.

\section{BULGULAR ve TARTIŞMA}

\section{Şırnak ili pamuk ekim alanlarında zararlı lepidoptera türlerinin belirlenmesi}

Arazi çalışmaları pamuğun temel gelişme, koza oluşturma ve olgunlaşma dönemlerini kapsayacak şekilde şekilde yürütülmüştür. Larvalar temel gelişme döneminde 2016 yılında özellikle 09.05.2016 ve 31.05.2016 tarihleri arasında, 2017 yılında ise 16.05.2017 ve 04.06.2017 tarihleri arasında Silopi'nin Kapılı, Verimli, Pınarönü, Üçağaç, Ortaköy, Özgen ve Dolan, Cizre'nin İnci, Bozalan ve Konak köylerinde yoğun olarak tespit edilmiştir (Çizelge 1). Çalışma yapılan 20 tarlada hemen her dönemde farklı Lepidoptera larvaları bulunmuştur. Arazide elde edilen larvalar laboratuvara getirilerek ergin elde etmek için kültüre alınmıştır. Çalışmanın birinci yılı sonunda Helicoverpa armigera Hubner (1805), Earias insulana Boisd (1833), Spodoptera exigua Hubner (1808) ve Agrotis ipsilon Hufnagel (1766) türleri belirlenmiştir. Pamuk alanlarındaki çalışmalar 2016 yılında 25.09.2016 tarihinde, 2017 yılında ise 22.09.2017 tarihinde pamuğun hasat edilmesiyle son bulmuştur. 
Çizelge 2.Silopi ve Cizre pamuk alanlarında 2016 yılında belirlenen Lepidoptera türleri ve bulundukları tarih aralıkları

Table 2. Species of Lepidoptera identified with their collection dates in cotton areas of Silopi and Cizre in 2016

\begin{tabular}{lcccc}
\hline Ilçe-Köy & Helicoverpa armigera & Earias insulana & Spodoptera exigua & Agrotis ipsilon \\
\hline Silopi-Özgen & 07.06 .2016 & 19.07 .2016 & 10.05 .2016 & 10.05 .2016 \\
& 30.08 .2016 & 30.08 .2016 & 07.06 .2016 & 24.05 .2016 \\
\hline Silopi-Pınarönü & 06.06 .2016 & 18.07 .2016 & 09.05 .2016 & 25.04 .2016 \\
& 29.08 .2016 & 29.08 .2016 & 23.05 .2016 & 23.05 .2016 \\
\hline Silopi-Kapılı & 07.06 .2016 & 19.07 .2016 & 10.05 .2016 & 10.05 .2016 \\
& 30.08 .2016 & 30.08 .2016 & 07.06 .2016 & 24.05 .2016 \\
\hline Silopi-Verimli & 07.06 .2016 & 19.07 .2016 & 10.05 .2016 & 10.05 .2016 \\
& 30.08 .2016 & 30.08 .2016 & 07.06 .2016 & 24.05 .2016 \\
\hline Silopi-Üçağaç & 06.06 .2016 & 18.07 .2016 & 09.05 .2016 & 25.04 .2016 \\
& 29.08 .2016 & 29.08 .2016 & 23.05 .2016 & 23.05 .2016 \\
\hline Silopi-Ortaköy & 06.06 .2016 & 18.07 .2016 & 09.05 .2016 & 25.04 .2016 \\
& 29.08 .2016 & 29.08 .2016 & 23.05 .2016 & 23.05 .2016 \\
\hline Silopi-Dolan & 06.06 .2016 & 18.07 .2016 & 09.05 .2016 & 25.04 .2016 \\
& 29.08 .2016 & 29.08 .2016 & 23.05 .2016 & 23.05 .2016 \\
\hline
\end{tabular}

Çizelge 2 (devamı). Silopi ve Cizre pamuk alanlarında 2016 yılında belirlenen Lepidoptera türleri ve bulundukları tarih aralıkları

Table 2 (continued). Species of Lepidoptera identified with their collection dates in cotton areas of Silopi and Cizre in 2016

\begin{tabular}{lllcc}
\hline Cizre-Inci & 12.07 .2016 & 12.07 .2016 & 03.05 .2016 & \multirow{2}{*}{17.05 .2016} \\
\hline Cizre-Bozalan & 06.09 .2016 & 06.09 .2016 & 31.05 .2016 & \multirow{2}{*}{17.05 .2016} \\
\hline Cizre-Konak & 12.07 .2016 & 12.07 .2016 & - & - \\
& 06.09 .2016 & 06.09 .2016 & & - \\
\hline
\end{tabular}

Çizelge 3. 2016 yılında pamuk alanlarında tespit edilen zararlı türlerin bulaşıklık durumları (\%)

Table 3. Infestation status of harmful species identified in 2016 in cotton areas (\%)

\begin{tabular}{lccccccc}
\hline Türler & \multicolumn{3}{c}{ Silopi } & \multicolumn{2}{c}{ Cizre } & Ortalama \\
& $\begin{array}{c}\text { Kontrol Edilen } \\
\text { Tarla Sayısı }\end{array}$ & $\begin{array}{c}\text { Bulaşık Tarla } \\
\text { Sayısı }\end{array}$ & $\begin{array}{c}\text { Bulaşıklık } \\
\text { Oranı }\end{array}$ & $\begin{array}{c}\text { Kontrol Edilen } \\
\text { Tarla Sayısı }\end{array}$ & $\begin{array}{c}\text { Bulaşık Tarla } \\
\text { Sayısı }\end{array}$ & $\begin{array}{c}\text { Bulaşıklık } \\
\text { Oranı }\end{array}$ & $\begin{array}{c}\text { Bulkılık } \\
\text { Oranı }\end{array}$ \\
\hline H. armigera & 16 & 16 & $\% 100$ & 4 & 4 & $\% 100$ & $\% 100$ \\
\hline E. insulana & 16 & 16 & $\% 100$ & 4 & 4 & $\% 100$ & $\% 100$ \\
\hline S. exigua & 16 & 14 & $\% 87.5$ & 4 & 3 & $\% 75$ & $\% 81,25$ \\
\hline A. ipsilon & 16 & 13 & $\% 81.25$ & 4 & 3 & $\% 78,13$ \\
\hline
\end{tabular}

Yapılan çalışma sonucunda türlerin 2016 yılında ki bulaşıklılık durumu ortalamalarına bakıldığında $H$. armigera ve $E$. insulana'nın bulaşıklık oranı \%100 olarak belirlenirken bunları sırasıyla $\% 81,25$ ve $\% 78,13$ ile $S$. exigua ve $A$. ipsilon takip etmiştir.
Çalışmanın ikinci yılı sonunda yine çalışma yapılan alanların tümünde $H$. armigera, $E$. insulana, S. exigua ve A. ipsilon türleri belirlenmiştir. Belirlenen Lepidopter türleri, bulundukları köyler ve görüldükleri tarih aralıkları Çizelge 3'te, bulaşıklık oranları ise Çizelge 4'te verilmiştir. 
Çizelge 4. Silopi ve Cizre pamuk alanlarında 2017 yılında belirlenen Lepidoptera türleri ve bulundukları tarih aralığı Table 4. Species of Lepidoptera identified with their collection dates in cotton areas of Silopi and Cizre in 2017

\begin{tabular}{lcccc}
\hline İlçe-Köy & Helicoverpa armigera & Earias insulana & Spodoptera exigua & Agrotis ipsilon \\
\hline Silopi-Özgen & 13.06 .2017 & 25.07 .2017 & 16.05 .2017 & 02.05 .2017 \\
& 22.08 .2017 & 05.09 .2017 & 30.06 .2017 & 30.05 .2017 \\
\hline Silopi-Pınarönü & 12.06 .2017 & 24.07 .2017 & 15.05 .2017 & 01.05 .2017 \\
& 04.09 .2017 & 04.08 .2017 & 29.05 .2017 & 29.05 .2017 \\
\hline Silopi-Kapılı & 28.09 .2017 & 26.07 .2017 & 03.05 .2017 & 03.05 .2017 \\
& 06.09 .2017 & 06.09 .2017 & 31.05 .2017 & 31.05 .2017 \\
\hline Silopi-Verimli & 27.06 .2017 & 25.07 .2017 & 16.05 .2017 & 02.05 .2017 \\
& 05.09 .2017 & 19.09 .2017 & 30.06 .2017 & 30.05 .2017 \\
\hline Silopi-Üçağaç & 26.06 .2017 & 24.07 .2017 & 15.05 .2017 & 01.05 .2017 \\
& 21.08 .2017 & 04.09 .2017 & 29.05 .2017 & 29.05 .2017 \\
\hline Silopi-Ortaköy & 29.06 .2017 & 27.07 .2017 & 04.05 .2016 & 04.05 .2017 \\
& 24.08 .2017 & 07.09 .2017 & 01.06 .2016 & 01.06 .2017 \\
\hline Silopi-Dolan & 14.06 .2017 & 26.07 .2017 & 17.05 .2017 & 03.05 .2017 \\
& 06.09 .2017 & 06.09 .2017 & 14.06 .2017 & 31.05 .017 \\
\hline Cizre-İnci & 14.07 .2017 & 28.07 .2017 & 05.05 .2017 & 19.05 .2017 \\
& 08.09 .2017 & 08.09 .2017 & 02.06 .2017 & 19.2017 \\
\hline Cizre-Bozalan & 14.07 .2017 & 28.07 .2017 & 05.05 .2017 & 19.05 .2017 \\
\hline Cizre-Konak & 08.09 .2017 & 08.09 .2017 & 02.06 .2017 & \\
& 14.07 .2017 & 28.07 .2017 & 05.05 .2017 & - \\
\hline
\end{tabular}

Çizelge 5. 2017 yılında pamuk alanlarında tespit edilen zararlı türlerin bulaşıklık durumları (\%)

Table 5. Infestation status of harmful species identified in 2017 in cotton areas (\%)

\begin{tabular}{lccccccc}
\hline Türler & \multicolumn{3}{c}{ Silopi } & \multicolumn{3}{c}{ Cizre } & \multicolumn{2}{c}{ Ortalama } \\
\hline & $\begin{array}{c}\text { Kontrol Edilen } \\
\text { Tarla Sayısı }\end{array}$ & $\begin{array}{c}\text { Bulaşık } \\
\text { Tarla Sayısı }\end{array}$ & $\begin{array}{c}\text { Bulaşıklık } \\
\text { Oranı }\end{array}$ & $\begin{array}{c}\text { Kontrol Edilen } \\
\text { Tarla Sayısı }\end{array}$ & $\begin{array}{c}\text { Bulaşık } \\
\text { Tarla Sayısı }\end{array}$ & $\begin{array}{c}\text { Bulaşıklık } \\
\text { Oranı }\end{array}$ & $\begin{array}{c}\text { Bulaşıklık } \\
\text { Oranı }\end{array}$ \\
\hline H. armigera & 16 & 16 & $\% 100$ & 4 & 4 & $\% 100$ & $\% 100$ \\
\hline E. insulana & 16 & 16 & $\% 100$ & 4 & 4 & $\% 100$ & $\% 100$ \\
\hline S. exigua & 16 & 14 & $\% 87.5$ & 4 & 4 & $\% 100$ & $\% 93,75$ \\
\hline A. ipsilon & 16 & 14 & $\% 87.25$ & 4 & 3 & $\% 75$ & $\% 81,25$ \\
\hline
\end{tabular}

Şırnak ili pamuk alanlarında örnekleme yapılan alanlardaki ortalama bulaşıklık oranlarına bakıldığında 2017 yılında $H$. armigera ve $E$. insulana'nın bulaşıklık oranı \%100 olarak belirlenirken bunları sırasıyla \%93,75 ve $\% 81,25$ ile $S$. exigua ve $A$. ipsilon takip etmiştir. Yapılan çalışmalar genel olarak değerlendirildiğinde ve iki yıl ortalamasındaki pamuk tarlalarının Lepidoptera türleri ile bulaşıklılık durumuna bakıldığında Helicoverpa armigera (\%100) ve Earias insulana (\%100) birinci sırada yer almış bunu sırasıyla Spodoptera exigua $(\% 87,5)$ ve Agrotis ipsilon $(\% 79,69)$ türleri takip etmiştir. Ünlü ve Kornoşor (2002) Şanlıurfa pamuk ekim alanlarında 19982000 yıllarında üç yıl süresince pembekurt $(P$. gossypiella) ve dikenlikurt (E. insulana) bulaşıklık oranlarının incelemişlerdir. Çalışma sonucunda, 19982000 yıllarında Harran Ovası'nda bulaşıklık oranları sırasıyla \%13.7, 43.1 ve 26.6; ilçelerde ise, \%16.6, 17.7 ve
8.2 olarak saptamışlardır. Pembe kurdun; Harran Ovası, Bozova, Suruç, Hilvan ilçelerinde; Dikenli kurdun da Viranşehir ve Ceylanpınar ilçelerinde yaygın olduğunu belirlemişlerdir. Büyük ve ark. (2002) Güneydoğu Anadolu Bölgesi pamuk ekilişlerinde 2001 yılında yürüttükleri çalışmada, Şanlıurfa ili Merkez, Akçakale ve Harran ilçelerinde yaklaşık 250 bin dekar alanın dikenlikurt ile bulaşık olduğunu belirtmişlerdir. Ayrıca Mardin ili Kızıltepe ilçesi ile Şanlıurfa ili Ceylanpınar ilçesi arasındaki pamuk ekiliş alanlarında genellikle fenolojisi geri ve ikinci ürün olarak ekilmiş tarlalarda popülasyonun daha yüksek olduğunu belirlemişlerdir. 
Pamuk ekim alanlarında belirlenen lepidoptera türlerinin popülasyon değişimi

Işık tuzakları ile ergin popülasyon değişiminin belirlenmesi
Pamuk alanlarında bulunan lepidopter türlerinin ergin popülasyon gelişimini takip etmek için 2016 yılında 20.04.2016, 2017 yılında ise 28.04.2017 tarihinde ışık tuzakları kurulmuştur.

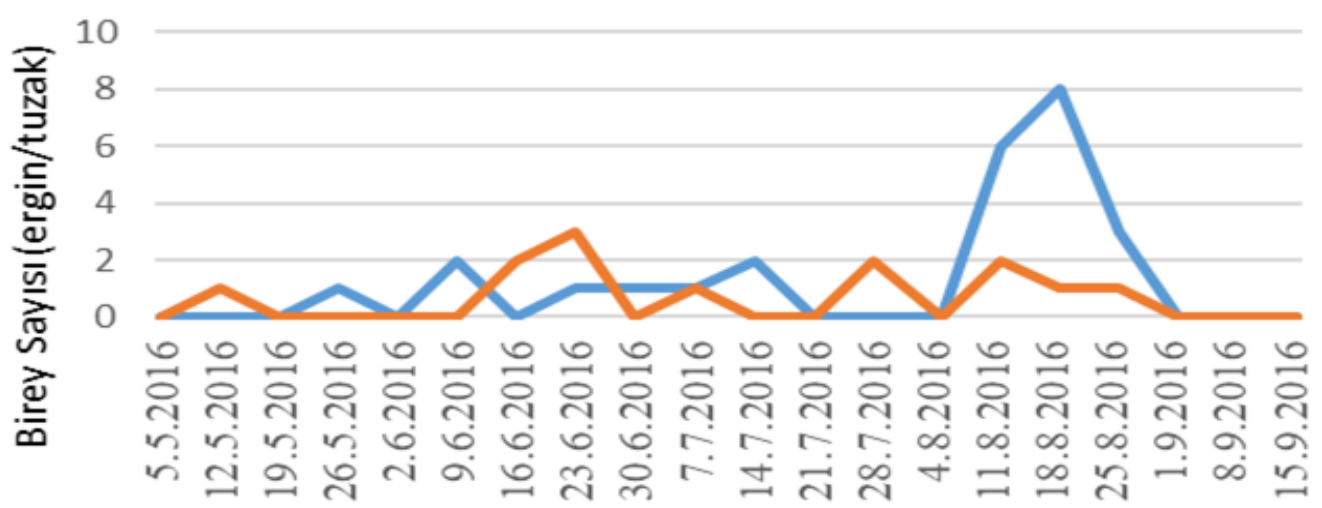

H. armigera

E. insulana

Tarih

Şekil 1. Silopi-Pınarönü Köyü pamuk tarlasındaki Lepidoptera türlerinin 2016 yılında ışık tuzağı ile belirlenen popülasyon değişimleri.

Figure 1. Population fluctuations of Lepidoptera species caught by light traps in the cotton field of Silopi-Pınarönü Villagein 2016.

Silopi-Pınarönü köyü ışık tuzağından 2016 yılında elde edilen veriler değerlendirildiğinde hemen her dönemde Helicoverpa armigera'nın bulunduğu, Earias insulana'nın ise daha düşük sayıda bulunduğu belirlenmiştir (Şekil 1). Pınarönü köyündeki pamuk tarlasına tuzağın kurulması ile birlikte mayıs ayından itibaren iki zararlının ergin bireyleri görülmeye başlanmıştır. Popülasyon seviyeleri değişiklik göstermiş ancak her iki zararlı da tüm fenolojik dönemlerde görülmüş, $H$. armigera 18.08.2016 tarihinde $8 \mathrm{ergin} /$ tuzak/hafta, $E$ insulana ise 23.06.2016 tarihinde 3 ergin/tuzak/hafta ile en yüksek popülasyon seviyesine ulaşmıştır.

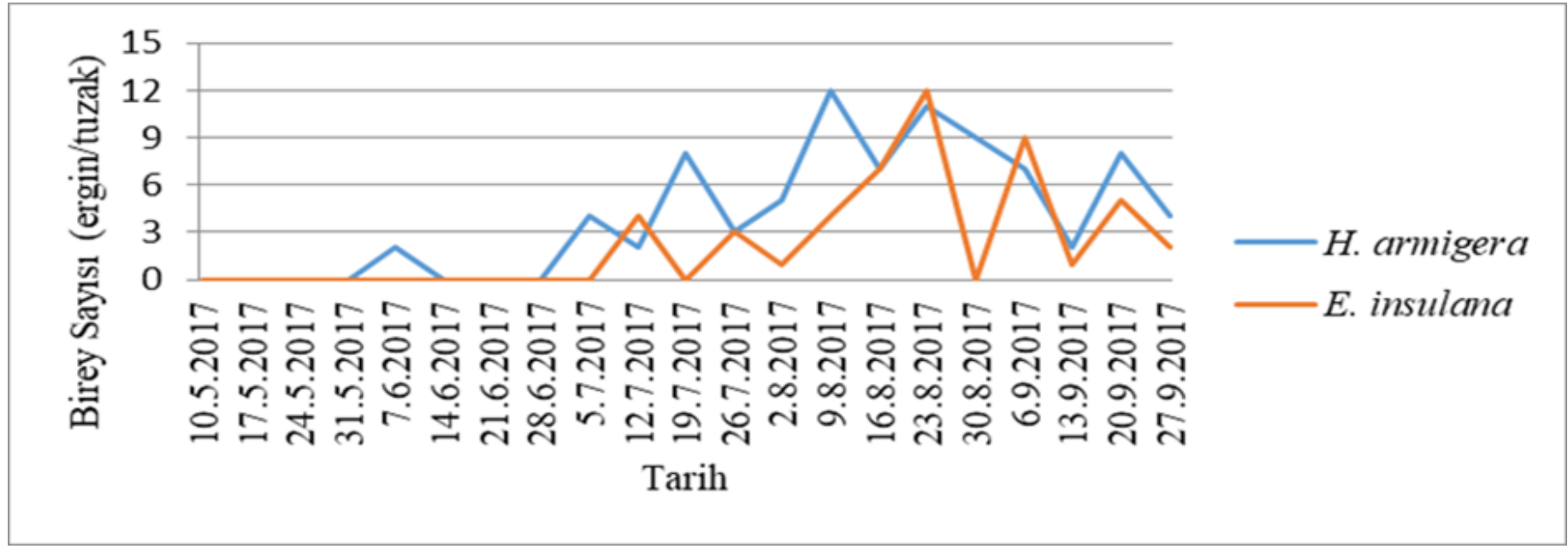

Şekil 2. Silopi-Pınarönü Köyü pamuk tarlasındaki Lepidoptera türlerinin 2017 yılında ışık tuzağı ile belirlenen popülasyon değişimleri.

Figure 2. Population fluctuations of Lepidoptera species caught by light traps in the cotton field of Silopi-Pınarönü Villagein 2017. 
Silopi-Pınarönü köyü pamuk tarlasındaki ışık tuzağında 2017 yılında elde edilen sonuçlara göre; 2016 yılında olduğu gibi mayıs ayının sonundan itibaren $H$. armigera'nın bulunduğu, $E$. insulana'nın ise temmuz ayında görülmeye başlandığı ve daha düşük sayıda olduğu Şekil 2.'de görülmektedir. H. armigera'nın 12 ergin/tuzak/hafta ile 09.08.2017 tarihinde, E. insulana'nın ise yine $12 \mathrm{ergin} /$ tuzak/hafta ile 23.08.2017 tarihinde en yüksek yoğunluğa ulaştığı görülmüştür.

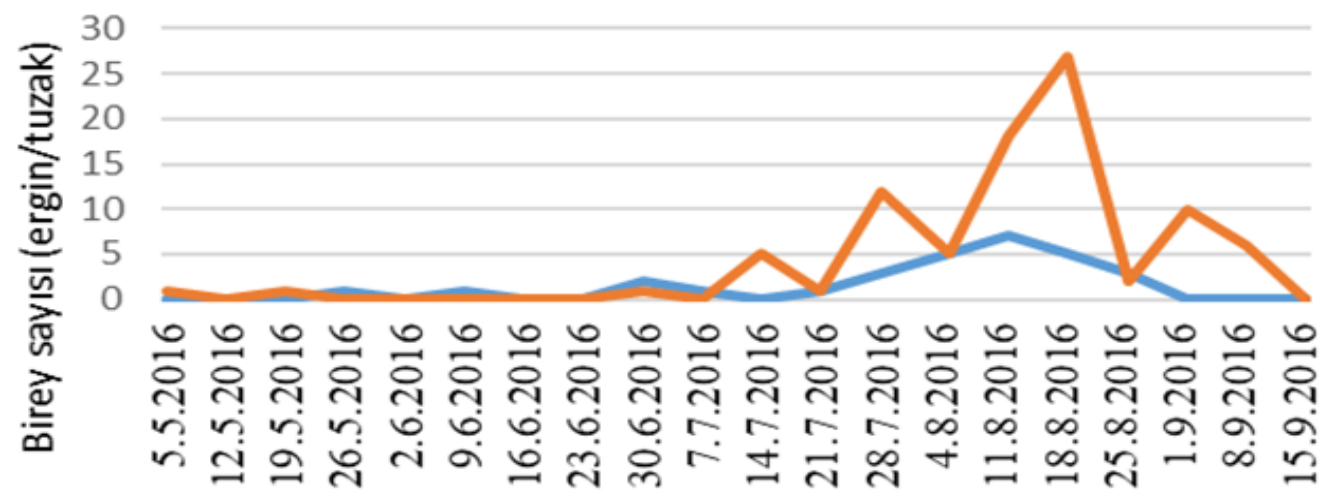

H. armigera

E. insulana

Tarih

Şekil 3. Silopi-Özgen köyü pamuk tarlasındaki Lepidoptera türlerinin 2016 yılında ışık tuzağı ile belirlenen popülasyon değişimleri.

Figure 3. Population fluctuations of Lepidoptera species caught by light traps in the cotton field of Silopi-Özgen Village in 2016.

Silopi-Özgen köyünde kurulan ışık tuzağından elde edilen zararlılara bakıldığında, yine $H$. armigera ve $E$. insulana'nın tuzağın kurulmasıyla birlikte görülmeye başlandığı belirlenmiştir. Işık tuzağı kontrollerinde $E$. insulana'nın sürekli bir şekilde bulunduğu, temmuz ayından itibaren popülasyonunun artırdığı ve 18.08.2016 tarihinde 27 ergin/tuzak/hafta ile en yüksek seviyeye ulaştığı görülmektedir. Tüm sezon boyunca tuzaklarda yakalanan $H$. armigera'da benzer şekilde temmuzağustos aylarında koza döneminde yoğun olarak bulunmuş ve 11.08 .2017 tarihinde 7 ergin/tuzak/hafta ile en yüksek seviyesine ulaşmıştır.

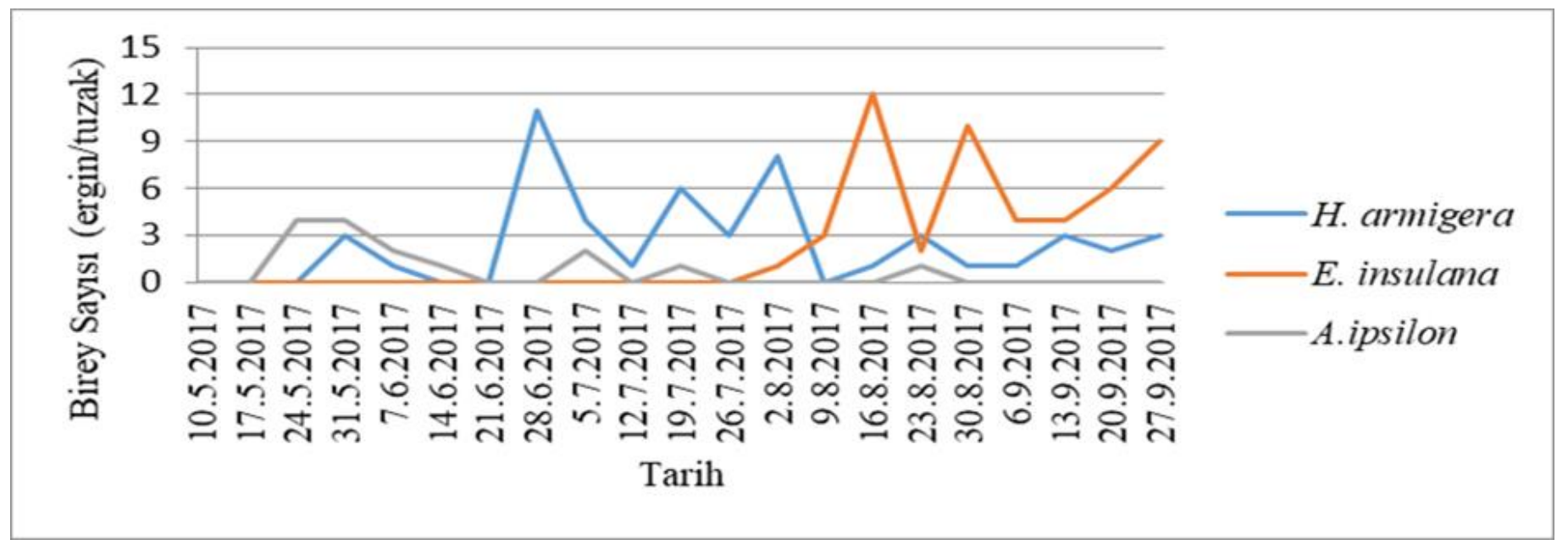

Şekil 4. Silopi-Özgen Köyü pamuk tarlasındaki Lepidoptera türlerinin 2017 yılında ışık tuzağı ile belirlenen popülasyon değişimleri.

Figure 4. Populationfluctuations of Lepidoptera species caught by light traps in the cotton field of Silopi-Özgen Villagein 2017.

Silopi-Özgen köyünde pamuk tarlasına kurulan ışık tuzağında 2017 yılında hem E. insulana'nın hemde
H.armigera'nın çıkıstan hemen sonra görülmeye başlandığı ve her dönemde bulunduğu belirlenmiştir. 
Earias insulana'nın özellikle 16.08.2017 tarihinde koza döneminde 12 ergin/tuzak/hafta ile en yüksek seviyeye ulaştığı görülmektedir. Helicoverpa armigera türüne bakıldığında her dönemde bulunduğu ve en yüksek sayıya 11 ergin/tuzak/hafta ile 28.06.2017 tarihinde, $A$. ipsilon türünün ise 4 ergin/tuzak/hafta ile fide döneminde 24.05.2017 ve 31.05.2017 tarihlerinde ulaştığı Şekil 4' te görülmektedir.

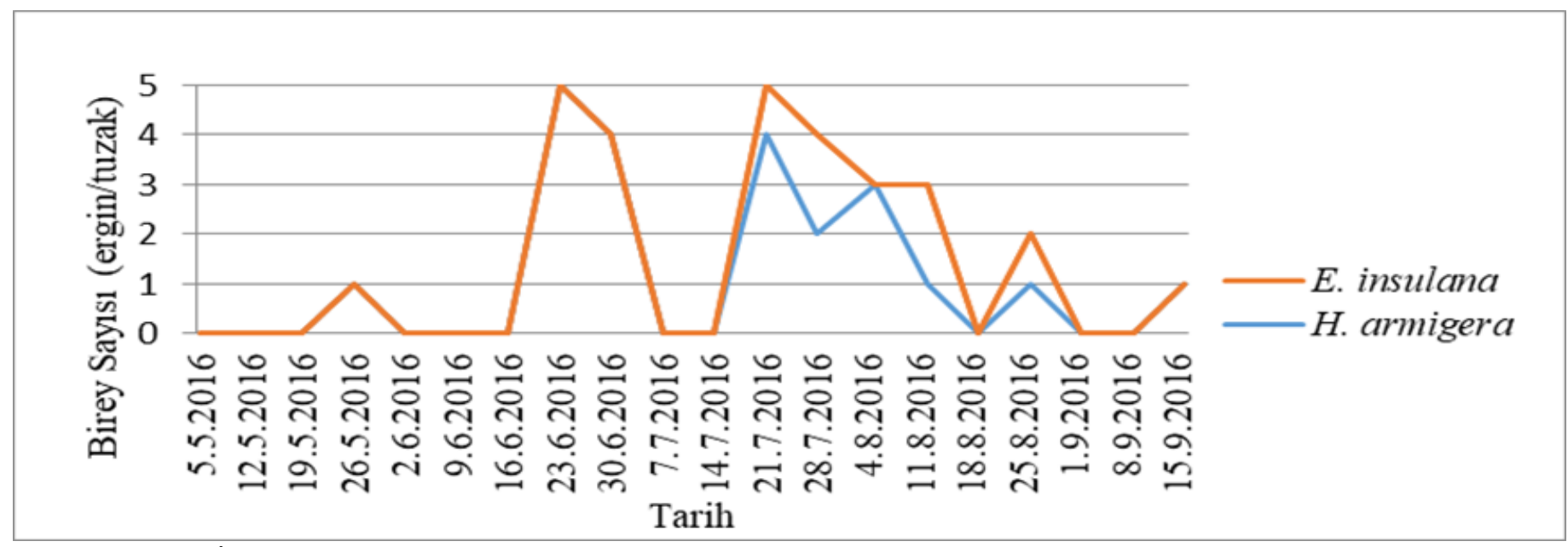

Şekil 5. Cizre-İnci Köyü pamuk tarlasındaki Lepidoptera türlerinin 2016 yılında ışık tuzağı ile belirlenen popülasyon değişimleri.

Figure 5. Population fluctuations of Lepidoptera species caught by light traps in the cotton field of Cizre-inci Village, in 2016.

Cizre-inci köyü pamuk tarlasında kurulan ışık tuzağında elde edilen birey sayılarına bakıldığında, Silopi ilçesindeki tarlalardan elde edilen bireylere göre daha düşük yoğunlukta olduğu görülmektedir. Ayrıca tuzaklar tarlalara kurulduktan 2 hafta sonra zararlı bireylere rastlanmaya başlanmıştır. İnci köyünde pamuk tarlasına kurulan ışık tuzağı verileri değerlendirildiğinde $E$. insulana türünün bitkilerin büyümeye başlamasıyla görüldüğü ve en yüksek seviyeye 5 ergin/tuzak/hafta ile 23.06.2016 ve 21.07.2016 tarihlerinde ulaştığı, $H$. armigera türünün ise daha düşük yoğunlukta kaldığı, koza başlangıcı ile görüldüğü ve en yüksek seviyeye 4 ergin/tuzak/hafta ile 21.07.2016 tarihinde ulaştığı görülmektedir.

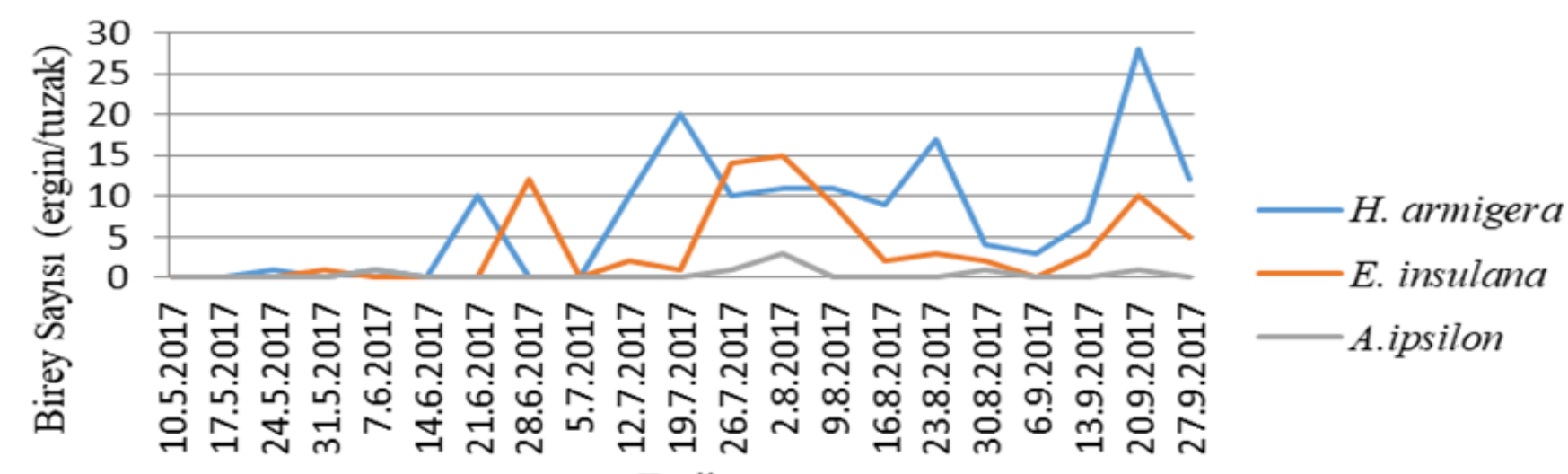

Tarih

Şekil 2. Cizre-İnci Köyü pamuk tarlasındaki Lepidoptera türlerinin 2017 yılında ışık tuzağı ile belirlenen popülasyon değişimleri.

Figure 6. Population fluctuations of Lepidoptera species caught by light traps in the cotton field of Cizre-Inci Village, in 2017. 
Cizre-inci köyünde pamuk tarlasına kurulan ışık tuzağından 2017 yılında elde edilen zararlılara bakıldığında $H$. armigera'nın ve $E$. insulana'nın yoğun bir şekilde ve her dönemde bulunduğu, $A$. ipsilon türünün ise çok düşük sayıda bulunduğu görülmektedir. $H$. armigera'nın ve $E$. insulana türlerinin özellikle haziran ayından itibaren sayılarının arttığı ve hasada yakın dönemde yüksek seviyelerde olduğu görülmektedir. $E$. insulana'nın 15 ergin/tuzak/hafta ile 02.08.2017 tarihinde, $H$. armigera türünün 28 ergin/tuzak/hafta ile 20.09.2017 tarihinde ve $A$. ipsilon türünün ise 3 ergin/tuzak/hafta ile 02.08.2017 tarihinde en yüksek seviyeye ulaştığı Şekil 6'da görülmektedir. Khalig ve Yousaf (1986) tarafından Pakistan'da pamukta bazı zararlı böceklerin ışık tuzaklarıyla yakalanmasında iklim şartlarının etkisini araştırılmıştır. Yapılan bu çalışmada $H$. armigera, Earias vitella, E. insulana, P. gossypiella ve Amrasca devastans'ı ışı tuzaklarında tespit etmişlerdir. Popescu (1990), Romanya'da ışık tuzaklarıyla $H$. armigera, $A$. ipsilon ve $A$. segetum'un populasyon gelişimi üzerine çalışmıştır. H. armigera'nın daha yaygın olduğunu ve eylül ayında epidemi yaptığını belirtmiştir.
A. ipsilon'un ise kesikli bir uçuş süresi olmasına rağmen nisan ayında başlayan uçuşların aralık başlarına kadar sürdüğünü ve populasyonun da giderek arttığını belirlemiştir. Ünlü ve ark. (2005) Harran Ovası'nda 20022003 yıllarında yaptıkları çalışmada, dikenlikurt erginlerinin ışık tuzaklarında temmuz ayında saptandığını ve her iki yılda da biri eylül, diğeri ekim ayı olmak üzere iki tepe noktası oluşturduğunu belirtmişlerdir.

\section{Feromon tuzakları ile pamuk alanlarında lepidoptera türlerinin ergin popülasyon değişimilerinin belirlenmesi Çalışmanın bu bölümünde Şırnak ili Cizre ve Silopi içlerinde ki pamuk alanlarında bulunan yeşilkurt, dikenlikurt ve pembekurt ergin popülasyonu gelişimini takip edebilmek için belirlenen pamuk alanlarına 2016 yılında 25.05.2016 tarihinde, 2017 yılında ise 28.04.2017 tarinde feromon tuzaklar kurulmuştur. Alanlara kurulan tuzaklar haftalık olarak düzenli bir şekilde kontrol edilmiş ve yakalanan bireyler kayıt altına alınmıştır. Böylece alanlarda bulunan türlerin ergin popülasyon grafikleri oluşturmuştur.}

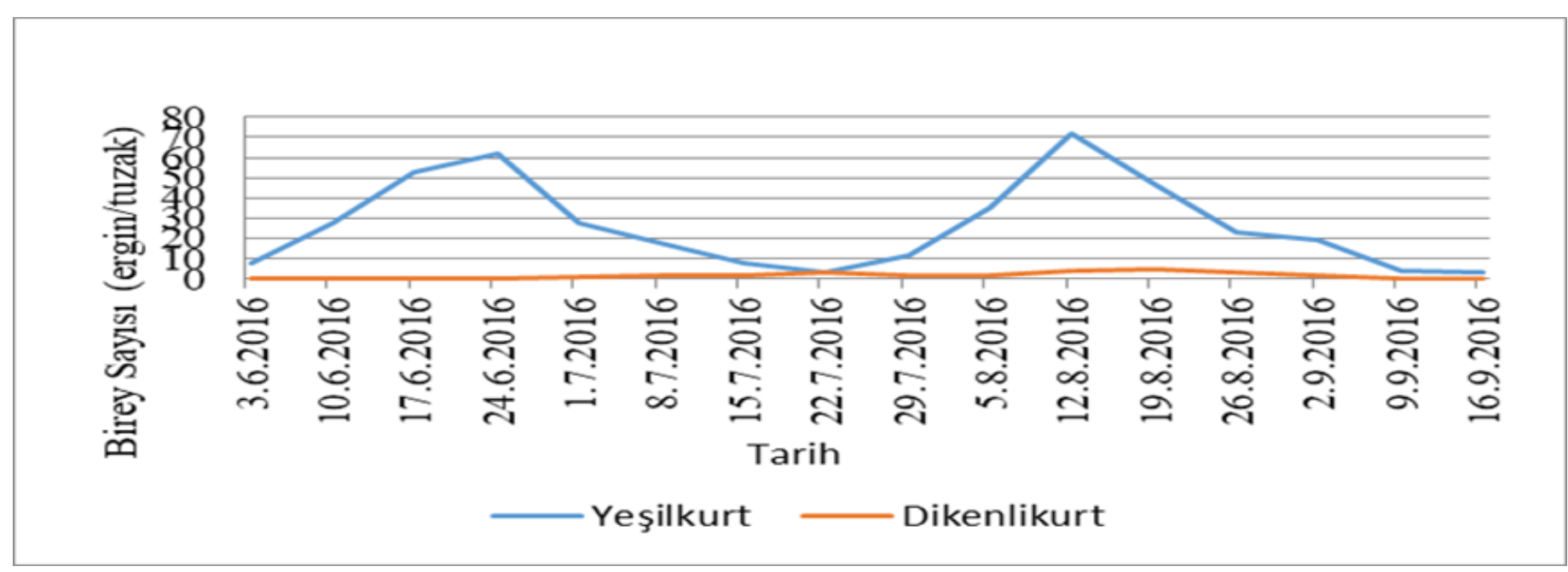

Şekil 7. Silopi-Pınarönü köyü pamuk tarlasındaki Lepidoptera türlerinin 2016 yılında feromon tuzağı ile belirlenen popülasyon değişimleri.

Figure 7. Population fluctuations of Lepidoptera species caught by pheromone traps in the cotton field of SilopiPınarönü village, in 2016.

Silopi-Pınarönü köyündeki feromon tuzaklardan 2016 yılında elde edilen veriler değerlendirildiğinde, feromon tuzaklarda H. armigera bireylerinin 03.06.2016 tarihinden, E. insulana bireylerinin ise 01.07.2016 tarihinden itibaren görülmeye başlamıştır. Çalışma sonucunda yapılan genel değerlendirmede $H$. armigera kelebeklerinin çok daha yoğun olarak tuzaklara yakalandığı ve 12.08.2016 tarihinde tuzağa gelen kelebek sayısının 72 ergin/tuzak/hafta olduğu görülmüştür (Şekil 7). E. insulana kelebekleri ise çok daha düşük sayılarda tuzağa gelmişlerdir. 


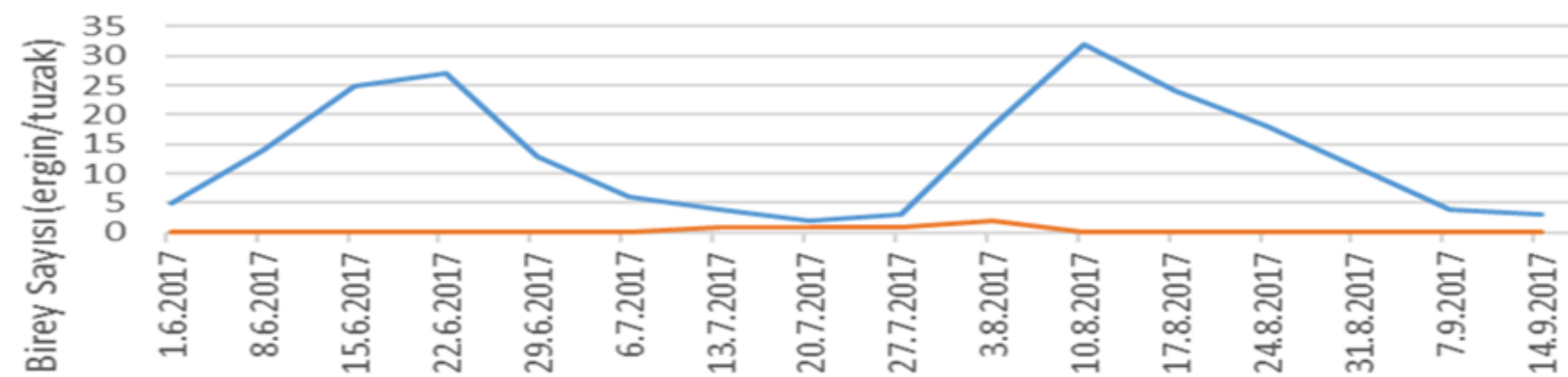

Tarih

- Yeşilkurt Dikenlikurt

Şekil 8. Silopi-Pınarönü köyü pamuk tarlasındaki Lepidoptera türlerinin 2017 yılında feromon tuzağı ile belirlenen popülasyon değişimleri.

Figure 8. Population fluctuations of Lepidoptera species caught by pheromone traps in the cotton field of SilopiPınarönü village in 2017.

Silopi-Pınarönü köyü feromon tuzaklarına 2017 yılı çalışmalarında gelen kelebekler değerlendirildiğinde $H$. armigera erginlerinin bu yılda yoğun olarak tuzaklara yakalandığı görülmektedir. Tuzaklarda $H$. armigera ilk olarak 01.06.2017 tarihinde E. insulana ise 13.07.2017 tarihinde görülmüştür. Çalışma süresince elde edilen veriler değerlendirildiğinde 10.08.2017 tarihinde tuzağa gelen $H$. armigera sayısının 32 ergin/tuzak/hafta olduğu ve en yüksek seviyeye ulaştığı belirlenmiştir (Şekil 8). $E$. insulana kelebekleri ise daha düşük yoğunlukta tuzağa gelmişlerdir.
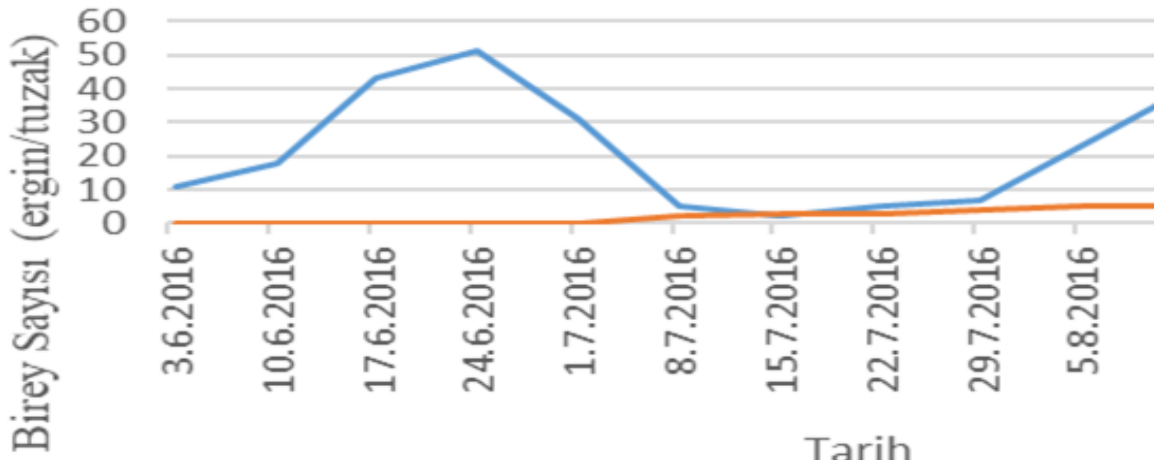

Tarih

Yeşilkurt

Dikenlikurt

Şekil 9. Silopi-Özgen köyü pamuk tarlasındaki Lepidoptera türlerinin 2016 yılında feromon tuzağı ile belirlenen popülasyon değişimleri.

Figure 9. Population fluctuations of Lepidoptera species caught by pheromone traps in the cotton field of Silopi-Özgen village in 2016.

Silopi-Özgen köyü feromon tuzakları ile yapılan çalışma değerlendirildiğinde $H$. armigera kelebeklerinin yoğun olarak tuzaklara yakalanan tür olduğu görülmektedir. Feromon tuzakların kontrolünde $H$. armigera'nın ilk olarak 03.06.2016 tarihinde, E. insulana'nın ise
08.07.2016 tarihinde tuzaklara geldiği görülmüştür. Çalışma sonunda 24.06.2016 tarihinde tuzağa gelen $H$. armigera sayısının en yüksek seviyeye 52 ergin/tuzak/hafta ile ulaştığı görülmüştür. 


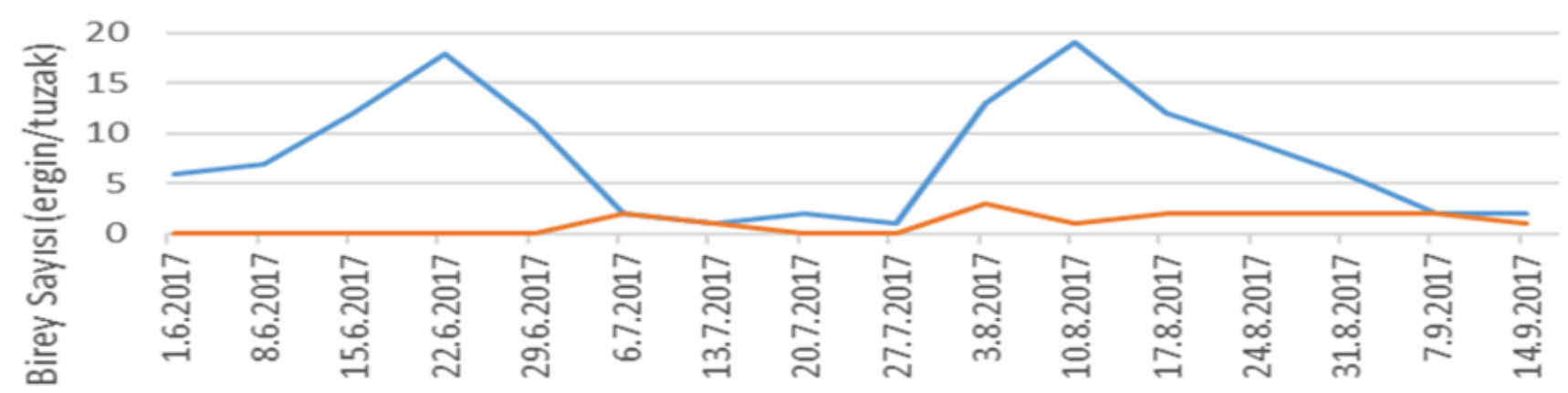

Tarih

\section{- Yeşilkurt Dikenlikurt}

Şekil 10. Silopi-Özgen köyü pamuk tarlasındaki Lepidoptera türlerinin 2017 yılında feromon tuzağı ile belirlenen popülasyon değişimleri.

Figure 10. Population fluctuations of Lepidoptera species caught by pheromone traps in the cotton field of SilopiÖzgen village in 2017.

Silopi-Özgen köyü feromon tuzaklarında 2017 yılında yapılan çalışmaların sonucuna bakıldığında $H$. armigera kelebeklerinin yine yoğun olarak tuzaklara yakalandığı görülmektedir. Tuzaklarda $H$. armigera ilk olarak 01.06.2017 tarihinde E. insulana ise 06.07.2017 tarihinde görülmüştür. Çalışma genel olarak değerlendirildiğinde 10.08.2017 tarihinde $H$. armigera sayısının 19 ergin/tuzak/hafta ile en yüksek yoğunluğa ulaştığı tespit edilmiştir (Şekil 10). Feromon tuzaklarda ki E. insulana kelebekleri ise daha düşük sayılarda tuzağa gelmişlerdir.

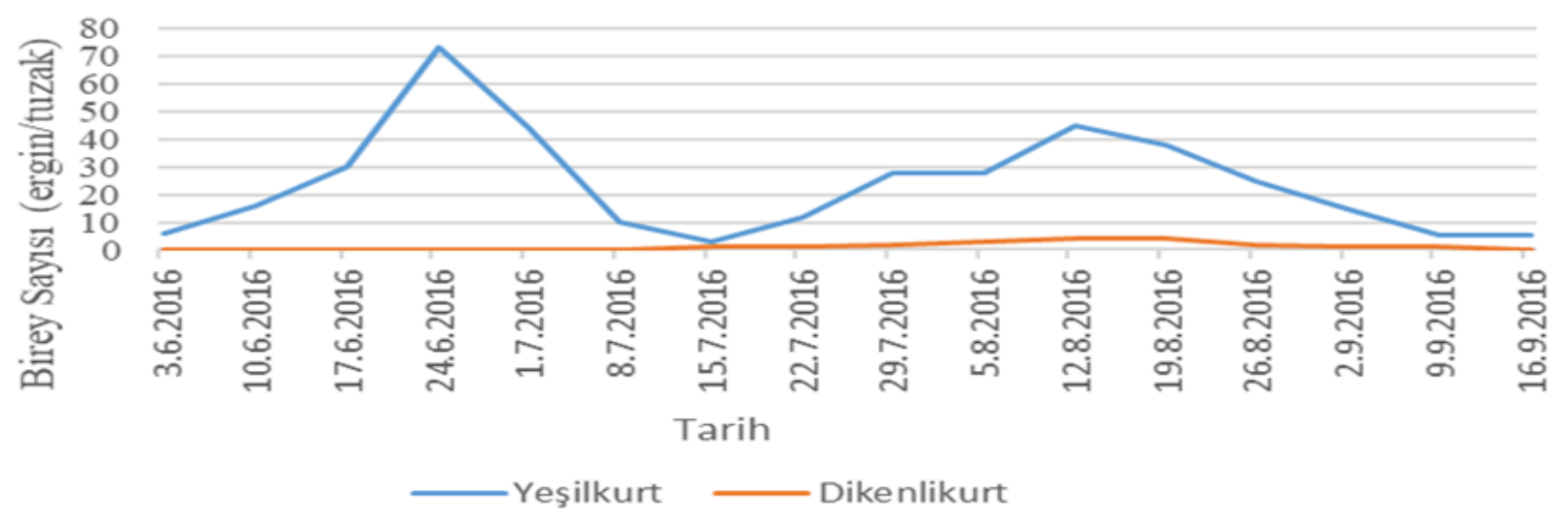

Şekil 11. Cizre-İnci köyü pamuk tarlasındaki Lepidoptera türlerinin 2016 yılında feromon tuzağı ile belirlenen popülasyon değişimleri.

Figure 11. Population fluctuations of Lepidoptera species caught by pheromone traps in the cotton field of Cizre-Inci village in 2016.

Cizre-İnci köyü feromon tuzaklarına gelen kelebekler kontrol edildiğinde; $H$. armigera erginlerinin daha yoğun olarak tuzaklara yakalandığı görülmektedir. Feromon tuzaklar kontrol edildiğinde $H$. armigera'nın ilk olarak 03.06.2016 tarihinde E. insulana'nın ise 15.07.2016 tarihinde görülmüştür. Çalışma sonucunda veriler değerlendirildiğinde 24.06.2016 tarihinde tuzağa gelen H. armigera sayısının 73 ergin/tuzak/hafta olduğu görülmüştür (Şekil 11). E. insulana erginlerinin yoğunluğu ise düşük bir seyir izlemiştir. 


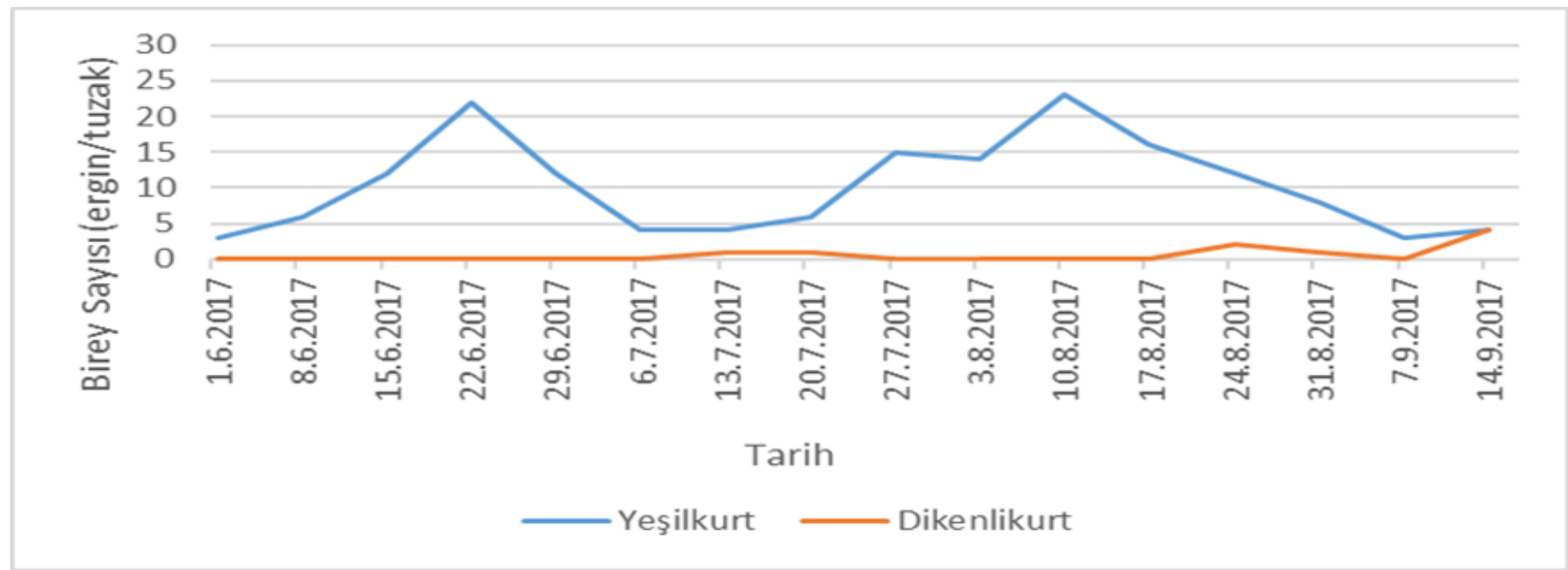

Şekil 12. Cizre-İnci köyü pamuk tarlasındaki Lepidoptera türlerinin 2017 yılında feromon tuzağı ile belirlenen popülasyon değişimleri.

Figure 12. Population fluctuations of Lepidoptera species caught by pheromone trapsin the cotton field of Cizre-Inci village in 2017.

Cizre-İnci köyü feromon tuzaklarından 2017 yılı çalışmalarında $H$. armigera kelebeklerinin 2016 yılında olduğu gibi yoğun olarak tuzaklara yakalandığı görülmektedir. Feromon tuzaklarda $H$. armigera ilk olarak 01.06.2017 tarihinde E. insulana ise 13.07.2017 tarihinde görülmüştür. Çalışma sonucunda 10.08.2017 tarihinde tuzağa gelen $H$. armigera sayısının 23 ergin/tuzak/hafta olduğu belirlenmiştir. Feromon tuzaklarda $E$. insulana kelebekleri ise daha düşük yoğunlukta tespit edilmiştir.

Qureshi ve Ahmed (1991), E. insulana'nın eşeysel feromon tuzakları ile mevsimsel popülasyon dalgalanmasını incelemişler ve yakalanan erginler ile pamuk kozalarında larva zararı arasındaki ilişkileri ortaya koymuşlardır. Pamuğun koza oluşturma dönemindeki larva popülasyonu ve feromon tuzağında ki erginlerin sayısı, bitkinin gelişmesi ile artmıştır. Ergin popülasyonunun tepe noktası ve larva zararı ağustos ve ekim aylarında gözlemlenmiştir. Moawad ve ark. (1994), Mısır pamuk alanlarında feromon tuzak kullanarak pembekurt ve dikenlikurt populasyonlarının tarla içindeki dağıımlarını araştırmışlardır. Çalışma sonucunda iki zararlının da populasyonlarının tarla içinde rastgele bir dağılım gösterdiği belirlenmiştir. Akyıldız ve Bayhan (2018), Diyarbakır ilinde 2014-2015 yıllarında delta tibi feromon tuzak kullanarak yürüttükleri çalışmada Yeşilkurdun popülasyon dalgalanmasının aylara ve yıllara göre değişiklik gösterdiğini belirtmişlerdir. Denemelerin yürütüldüğü alanlarda 2014 yılında 2015 yılına oranla daha fazla kelebek yakalandığını bildirmişlerdir.

\section{Pamuk alanlarında tespit edilen lepidoptera türlerinin avcılarının belirlenmesi}

Silopi ve Cizre ilçelerinde çalışmaların yürütüldüğü pamuk tarlalarında 2016 ve 2017 yıllarında elde edilen predatör türler çizelgelerde verilmiştir (Çizelge 5.6.7.8). Çalışmada Cizre ve Silopi ilçelerindeki pamuk tarlalarında, atrap sallama yöntemi ile Coccinellidae (Coleoptera), Carabidae (Coleoptera), Staphylinidae (Coleoptera), Syrphidae (Diptera), Anthocoridae (Hemiptera), Lygaeidae (Hemiptera), Miridae (Hemiptera), Nabidae (Hemiptera), Sphecidae (Hymenoptera) ve Chrysopidae (Neuroptera) familyalarına ait predatör türleri belirlenmiştir. 
Çizelge 6. Silopi'de pamuk tarlalarında 2016 yılında belirlenen avcı türler ve sayıları (adet)

Table 6. Predatory insect species and their total numbersin cotton fields of Silopi in 2016

\begin{tabular}{|c|c|c|c|c|c|c|c|c|}
\hline Predatör Tür/Familya & Kapılı & Verimli & Üçağaç & Dolan & Özgen & Pınarönü & Ortaköy & Toplam \\
\hline $\begin{array}{l}\text { Coccinella semptempunctata } \\
\text { (Col: Coccinellidae) }\end{array}$ & 3 & 5 & 2 & 3 & 4 & 2 & 0 & 19 \\
\hline $\begin{array}{l}\text { Exochomus quadripustulatus } \\
\text { (Col: Coccinellidae) }\end{array}$ & 0 & 0 & 0 & 0 & 0 & 1 & 1 & 2 \\
\hline $\begin{array}{l}\text { Hippodamia variegata } \\
\text { (Col: Coccinellidae) }\end{array}$ & 5 & 2 & 3 & 6 & 4 & 7 & 2 & 29 \\
\hline $\begin{array}{l}\text { Scymnus subvillosus } \\
\text { (Col: Coccinellidae) }\end{array}$ & 0 & 0 & 0 & 2 & 3 & 2 & 0 & 7 \\
\hline $\begin{array}{l}\text { Synharmonia conglobata } \\
\text { (Col: Coccinellidae) }\end{array}$ & 0 & 0 & 0 & 0 & 0 & 2 & 1 & 3 \\
\hline $\begin{array}{l}\text { Paederus fuscipes } \\
\text { (Col: Staphylinidae) }\end{array}$ & 0 & 0 & 0 & 0 & 0 & 1 & 1 & 2 \\
\hline Cicindela campestris (Col:Carabidae) & 0 & 0 & 0 & 0 & 0 & 2 & 2 & 4 \\
\hline $\begin{array}{l}\text { Episyrphus sp. } \\
\text { (Dip: Syrphidae) }\end{array}$ & 0 & 0 & 0 & 1 & 0 & 0 & 0 & 1 \\
\hline $\begin{array}{l}\text { Orius sp. } \\
\text { (Hem: Anthocoridae) }\end{array}$ & 0 & 0 & 0 & 3 & 0 & 0 & 0 & 3 \\
\hline $\begin{array}{l}\text { Deraeocoris pallens } \\
\text { (Hem: Miridae) }\end{array}$ & 14 & 9 & 10 & 8 & 11 & 8 & 6 & 66 \\
\hline Geocoris pallens (Hem:Lygaeidae) & 0 & 0 & 0 & 0 & 0 & 3 & 2 & 5 \\
\hline $\begin{array}{l}\text { Nabis pseudoferus } \\
\text { (Hem: Nabidae) }\end{array}$ & 8 & 7 & 6 & 9 & 5 & 11 & 6 & 52 \\
\hline $\begin{array}{l}\text { Sphecidae } \\
\text { (Hymenoptera) }\end{array}$ & 0 & 0 & 0 & 0 & 0 & 1 & 0 & 1 \\
\hline $\begin{array}{l}\text { Chrysoperla carnea } \\
\text { (Neu: Chrysopidae) }\end{array}$ & 12 & 8 & 11 & 13 & 10 & 15 & 19 & 88 \\
\hline Toplam & 42 & 31 & 32 & 45 & 37 & 55 & 40 & 274 \\
\hline
\end{tabular}


Çizelge 7. Silopi'de pamuk tarlalarında 2017 yılında belirlenen avcı türler ve sayıları (adet)

Table 7. Predatory species and their total numbers in cotton fields of Silopi in 2017

\begin{tabular}{lccccccccc}
\hline Predatör Tür/Familya & Kapılı & Verimli & Üçağaç & Dolan & Özgen & Pınarönü & Ortaköy & Toplam \\
\hline $\begin{array}{l}\text { Cicindela campestris } \\
\text { (Col:Carabidae) }\end{array}$ & 0 & 0 & 0 & 0 & 0 & 2 & 2 & 4 \\
\hline $\begin{array}{l}\text { Coccinella semptempunctata } \\
\text { (Col: Coccinellidae) }\end{array}$ & 3 & 6 & 2 & 3 & 5 & 2 & 0 & 21 \\
\hline $\begin{array}{l}\text { Exochomus quadripustulatus } \\
\text { (Col: Coccinellidae) }\end{array}$ & 0 & 1 & 0 & 0 & 0 & 1 & 1 & 3 \\
\hline $\begin{array}{l}\text { Hippodamia variegata } \\
\text { (Col: Coccinellidae) }\end{array}$ & 3 & 2 & 3 & 4 & 4 & 7 & 2 & 25 \\
\hline $\begin{array}{l}\text { Scymnus subvillosus } \\
\text { (Col: Coccinellidae) }\end{array}$ & 0 & 0 & 0 & 2 & 3 & 2 & 0 & 7 \\
\hline $\begin{array}{l}\text { Synharmonia conglobata } \\
\text { (Col: Coccinellidae) }\end{array}$ & 0 & 0 & 0 & 0 & 0 & 2 & 1 & 3 \\
\hline $\begin{array}{l}\text { Paederus fuscipes } \\
\text { (Col: Staphylinidae) }\end{array}$ & 0 & 0 & 0 & 0 & 0 & 1 & 1 & 2 \\
$\begin{array}{l}\text { Episyrphus sp. } \\
\text { (Dip: Syrphidae) }\end{array}$ & 0 & 0 & 0 & 2 & 0 & 3 & 0 & 5 \\
\hline $\begin{array}{l}\text { Orius sp. } \\
\text { (Hem: Anthocoridae) }\end{array}$ & 0 & 0 & 0 & 3 & 3 & 4 & 6 & 16 \\
\hline $\begin{array}{l}\text { Geocoris pallens } \\
\text { (Hem: Lygaeidae) }\end{array}$ & 0 & 4 & 2 & 0 & 0 & 3 & 2 & 11 \\
\hline $\begin{array}{l}\text { Deraeocoris pallens } \\
\text { (Hem: Miridae) }\end{array}$ & 8 & 11 & 13 & 7 & 8 & 10 & 5 & 62 \\
\hline $\begin{array}{l}\text { Nabis pseudoferus } \\
\text { (Hem: Nabidae) }\end{array}$ & 6 & 5 & 4 & 5 & 5 & 7 & 6 & 38 \\
\hline $\begin{array}{l}\text { Sphecidae } \\
\text { (Hymenoptera) }\end{array}$ & 14 & 10 & 11 & 8 & 14 & 18 & 19 & 94 \\
\hline $\begin{array}{l}\text { Chrysoperla carnea } \\
\text { (Neu: Chrysopidae) }\end{array}$ & 39 & 35 & 34 & 42 & 64 & 45 & 304 \\
\hline \begin{tabular}{l} 
Toplam \\
\hline
\end{tabular} & 0 & 0 & 0 & 0 & 2 & 0 & 2 \\
\hline
\end{tabular}


Çizelge 8. Cizre' de pamuk tarlalarında 2016 yılında belirlenen avcı türler ve sayıları (adet)

Table 8. Predatory species and their total numbers determined in cotton fields of Cizre in 2016

\begin{tabular}{|c|c|c|c|c|}
\hline Predatör Tür & Bozalan & Konak & İnci & Toplam \\
\hline $\begin{array}{l}\text { Coccinella semptempunctata } \\
\text { (Col: Coccinellidae) }\end{array}$ & 3 & 5 & 4 & 12 \\
\hline $\begin{array}{l}\text { Exochomus quadripustulatus } \\
\text { (Col: Coccinellidae) }\end{array}$ & 0 & 1 & 0 & 1 \\
\hline $\begin{array}{l}\text { Hippodamia variegata } \\
\text { (Col: Coccinellidae) }\end{array}$ & 0 & 1 & 0 & 1 \\
\hline $\begin{array}{l}\text { Scymnus subvillosus } \\
\text { (Col: Coccinellidae) } \\
\end{array}$ & 1 & 0 & 2 & 3 \\
\hline Cicindela campestris (Col:Carabidae) & 1 & 0 & 0 & 1 \\
\hline $\begin{array}{l}\text { Paederus fuscipes } \\
\text { (Col: Staphylinidae) }\end{array}$ & 1 & 0 & 3 & 4 \\
\hline $\begin{array}{l}\text { Deraeocoris pallens } \\
\text { (Hem: Miridae) }\end{array}$ & 3 & 3 & 7 & 13 \\
\hline $\begin{array}{l}\text { Geocoris pallens } \\
\text { (Hem:Lygaeidae) }\end{array}$ & 1 & 1 & 0 & 2 \\
\hline \multicolumn{4}{|c|}{ Çizelge 8 (devamı). Cizre' de pamuk tarlalarında 2016 yılında belirlenen avcı türler ve sayıları (adet) } & Table 8 (continued). Predatory species and their total numbers determined in cotton fields of Cizre in 2016 \\
\hline $\begin{array}{l}\text { Nabis pseudoferus } \\
\text { (Hem: Nabidae) }\end{array}$ & 3 & 6 & 8 & 17 \\
\hline $\begin{array}{l}\text { Chrysoperla carnea } \\
\text { (Neu: Chrysopidae) }\end{array}$ & 7 & 10 & 13 & 30 \\
\hline Toplam & 20 & 27 & 37 & 84 \\
\hline
\end{tabular}

Çizelge 9. Cizre'de pamuk tarlalarında 2017 yılında belirlenen avcı türler ve sayıları (adet)

Table 9. Predatory species and their total numbers in cotton fields of Cizre in 2017

\begin{tabular}{|c|c|c|c|c|}
\hline Predatör Tür & Bozalan & Konak & İnci & Toplam \\
\hline $\begin{array}{l}\text { Cicindela campestris } \\
\text { (Col:Carabidae) }\end{array}$ & 1 & 1 & 0 & 2 \\
\hline $\begin{array}{l}\text { Coccinella semptempunctata } \\
\text { (Col: Coccinellidae) }\end{array}$ & 5 & 6 & 2 & 13 \\
\hline $\begin{array}{l}\text { Exochomus quadripustulatus } \\
\text { (Col: Coccinellidae) }\end{array}$ & 0 & 1 & 0 & 1 \\
\hline $\begin{array}{l}\text { Hippodamia variegata } \\
\text { (Col: Coccinellidae) }\end{array}$ & 0 & 2 & 1 & 3 \\
\hline $\begin{array}{l}\text { Scymnus subvillosus } \\
\text { (Col: Coccinellidae) }\end{array}$ & 1 & 2 & 2 & 5 \\
\hline $\begin{array}{l}\text { Paederus fuscipes } \\
\text { (Col: Staphylinidae) }\end{array}$ & 2 & 0 & 3 & 5 \\
\hline $\begin{array}{l}\text { Deraeocoris pallens } \\
\text { (Hem: Miridae) }\end{array}$ & 5 & 3 & 4 & 12 \\
\hline $\begin{array}{l}\text { Geocoris pallens } \\
\text { (Hem:Lygaeidae) }\end{array}$ & 1 & 1 & 0 & 2 \\
\hline $\begin{array}{l}\text { Nabis pseudoferus } \\
\text { (Hem: Nabidae) }\end{array}$ & 3 & 6 & 8 & 17 \\
\hline $\begin{array}{l}\text { Chrysoperla carnea } \\
\text { (Neu: Chrysopidae) }\end{array}$ & 12 & 8 & 11 & 31 \\
\hline Toplam & 30 & 30 & 31 & 91 \\
\hline
\end{tabular}


Adana ilinde 1989-1997 yılları arasında yaptığı doğal düşmanların etkinliklerini belirleme çalışmasında Ghavami'de (1999), Orius spp., Geocoris spp., Nabis spp., $D$. pallens ve $C$. carnea'nın dikenli kurdun yumurta ve ilk dönem larvalarıyla beslendiğini belirtmiştir. Mamay ve Yücel (2005) tarafından yapılan bir çalışmada Harran Ovası pamuk ekim alanlarında predatör türler olarak $H$. variegata, Stethorus gilvifrons (Mulsant), C. carnea, Nabis punctatus Costa, Geocoris megacephalus ( R.), Piocoris sp., Camptobrochis sp. ve Cardiastethus sp. nin bulunduğu bildirilmiştir. Başka bir çalışmada ise Göven ve Efil (1994), Dicle vadisi pamuk alanlarında yeşilkurdun predatörü olarak C. carnea, Orius spp., Nabis spp. ve Geocaris spp. türlerinin olduğunu belirlemişlerdir.

Sonuç olarak; girdi maliyetlerinin artışı neticesinde ülkemizdeki tarımsal potansiyelin azaldığı bu dönemde ülkemiz için çok önemli olan pamuğun zararlılara karşı en iyi şekilde korunması ve verim kayıplarının önüne geçilmesi gerekmektedir. Silopi ve Cizre'de pamuk alanlarında zararlı Lepidoptera türlerinin bulunduğu ve bitkide zarar oluşturduğu görülmüştür. Bu zararların önüne geçebilmek için tarla kontrollerinin yapılması ve gerekli görüldüğü takdirde teknik talimatlar doğrultusunda müdahale edilmesi gerekmektedir. Bölge için gelişimi ve verimi iyi olan çeşitlerin belirlenmesi ve entegre mücadele kapsamında öncelikle biyoteknik mücadele yollarının kullanılması ve çalışmada elde edilen zararlılar ile ilgili biyolojik kriterlerin kullanılarak mücadele uygulama takviminin hazırlanması uygun olacaktır. Pamuk alanlarında en önemli zararlı Lepidoptera türleri $H$. armigera ve $E$. insulana olarak belirlenmiştir. Bu zararlıların tarlada popülasyonlarının takip edilmesi ve bunlar nedeniyle doğacak verim kayıplarının önüne geçebilmek için öncelikle çalışmada saptanan zararlıların çıkış zamanları ve yoğunluklarıyla bitkinin fenolojik dönemleri dikkate alınarak mücadele zamanının belirlenmesi önerilir.

\section{ÖZET}

Amaç: Bu çalışma, 2016-2017 yıllarında Şırnak ili Cizre ve Silopi ilçelerinde pamuk alanlarındaki zararlı lepidopter türlerini, önemli türlerin popülasyon gelişimlerini, yoğunluklarını ve doğal düşmanlarını belirlemek için yürütülmüştür.

Yöntem ve Bulgular: Şırnak ili pamuk ekim alanlarında yürütülen çalışmada gözle kontrol yöntemi, ışık tuzağı ve feromon tuzağı yöntemleri kullanılmıştır. Heliotis armigera ve Earias insulana'nın çalışma yapılan her alanda bulunduğu ve mücadele yapılmadığı takdirde önemli zarar verdikleri gözlemlenmiştir. Şırnak ilindeki pamuk alanlarında yapılan bu çalışmada, belirlenen
Lepidoptera türlerinin predatörleri olarak, Coleoptera takımının Coccinellidae (beş tür) ve Carabidae (bir tür), Diptera takımının Syrphidae (bir tür); Hemiptera takımının Anthocoridae (bir tür), Nabidae (bir tür) ve Miridae (bir tür); Hymenoptera takımının Sphecidae (bir tür) ile Neuroptera takımının Chrysopidae (bir tür) familyasından giren toplam 15 tür tespit edilmiştir.

Genel Yorum: Çalışma sonucunda pamuk yetiştiriciliği yapılan alanlardan elde edilen lepidopter türlerden Helicoverpa armigera (Hübner) ve Earias insulana (Boisduval), en yaygın ve yoğun türler olarak belirlenmişlerdir. İkinci derecede zararlı türler ise Spodoptera exigua (Hübner) ve Agrotis ipsilon (Hufnagel) olarak tespit edilmiştir. Yoğun olarak görülen önemli predatör türlerin ise Coccinellidae, Miridae, Nabidae ve Chrysopidae familyasına giren türler olduğu görülmüştür.

Çalışmanın Önemi ve Etkisi: Elde edilen sonuçlar, bölge için gelişimi ve verimi iyi olan çeşitlerin belirlenmesi ve entegre mücadele kapsamında öncelikle biyoteknik mücadele yöntemlerinin kullanılması ve çalışmada elde edilen zararlılar ile ilgili biyolojik kriterlerin kullanılarak mücadele uygulama takviminin hazırlanmasının uygun olacağını göstermiştir.

Anahtar Kelimeler: Lepidoptera, pamuk, şırnak, popülasyon, zararlı.

\section{ÇIKAR ÇATIŞMA BEYANI}

Yazar(lar) çalışma konusunda çıkar çatışmasının olmadığını beyan eder.

\section{ARAŞTIRMACILARIN KATKI ORANI BEYANI}

Yazarlar çalışmaya eşit oranda katkı sağlamış olduklarını beyan eder.

\section{KAYNAKLAR}

A Abou-el Hagag GH (1998) Seasonal abundance of certain cotton pest and their associated natural enemies in Southern Egypt. AJAS 29(3): 253-267.

Abul-Nasr SE, Ammar ED, Merdan Al (1983) Field application of two strains of Bacillus thurigensis for the control of the cotton bollworms Pectinophora gossypiella (Sound.) and Earias insulana (Boisd.). Bull. Entomol. Soc. Egypt 11: 35-39.

Akyıldız M, Bayhan E (2018) Diyarbakır ili pamuk ekim alanlarında bulunan yeşilkurt, Helicoverpa armigera (Hübner) (Lepidoptera: Noctuidae)'un popülasyon dalgalanmasının belirlenmesi. Harran Tarım ve Gıda Bilimleri Derg. 22(2): 186-195 
Anonim

http://www.upk.org.tr/User_Files/editor/file/2019\% 20Pamuk\%20Raporu.pdf

(Erişim Tarihi: 16.03.2021)

Doğanlar, F. 2003. Doğu Akdeniz Bölgesi Geometridae (Lepidoptera) familyası üzerinde faunistik ve sistematik araştırmalar. Çukurova Üniversitesi, Fen Bilimleri Enstitüsü, Adana, 274 s.

Elmosa H (1986) Prospects of using sex pheromone for the control of spiny bollworm in cotton growing in Syria. Dirasat. 13 (5): 165-174.

Eren S (2006) Güneydoğu Anadolu Bölgesinde pamukta zararlı dikenlikurt (Earias insulana Boisd.)'un populasyon gelişimi, bulaşıklık oranı ve doğal düşmanlarının belirlenmesi. Yüksek Lisans Tezi. Harran Üniversitesi, Fen Bilimleri Enstitüsü, Bitki Koruma ABD. $58 \mathrm{~s}$.

Faseli MD (1977) Investigations on the biology, ecology and control of Earias insulana Boisd. (Noctuidae). Ent. et Phyto. 43: 39-54.

Ghavami MD (1999) Adana ili Karataş ve Balcalı pamuk tarlalarında doğal düşman türlerinin saptanması. Türkiye 4. Biyolojik Mücadele Kongresi, 26-29 Ocak, Adana, Türkiye. S: 541-552.

Göven MA, Efil L (1994) Dicle Vadisinde yeşilkurtun doğal düşmanları ve etkinlikleri üzerinde araştırmalar. Türkiye III. Biyolojik Mücadele Kongresi, 25-28 Ocak, İzmir, Türkiye. s.449-457.

Göven MA (1995) Güneydoğu Anadolu Bölgesi pamuk ekim alanlarındaki zararlılar ile ilgili sorunlar ve çözüm önerileri. GAP Bölgesi Bitki Koruma Sorunları ve Çözüm Önerileri Sempozyumu. 27-29 Nisan, Şanlıurfa, Türkiye. s.282-289.

Karman MŞ (1960) Ege pamuklarında pembekurt zararı, yayılışı ve mücadele metodları üzerinde çalışmalar. Bornova Zirai Mücadele Araştırma Enstitüsü Yayınları. Teknik Bülten:1, Gutenberg Matbaası, İzmir. 39s.

Kashyap RK, Verma AN (1987) Management of spotted bollworms (Earias spp.) in cotton -a Review. J. Trop. Agric. 5(1): 1-27.

Khalig A, Yousaf M (1986) Effect of weather on the light trap captures of some insect pests of cotton. JAR 24(4): 313-319.

Kıray Y (1964) Çukurova Bölgesi pamukları ve diğer kültür bitkilerinde zarar yapan Earias insulana Boisd. böceğininin biyolojisi ve mücadelesi üzerinde araştırmalar. Doktora Tezi. Çukurova Üniversitesi, Fen Bilimleri Enstitüsü, Bitki Koruma ABD. 119s.
Klein M, Navon A, Andreadou M, Keren S (1981) Development of an artifical diet for mass rearing of the spiny bollworm, Earias insulana. Phytoparasitica 9(2): 145-148.

Lodos N (1981) Maize pests ve their importance in Turkey. EPPO Bull. 11(2): 87-89.

Mamay M, Yücel A (2005). Harran Ovası pamuk ekim alanlarında zararlı olan Bemisia spp (Homoptera: Aleyrodidae)'nin popülasyon gelişimi ve doğal düşmanlarının belirlenmesi. GAP 4. Tarım Kongresi, 21-23 Eylül, Şanlıurfa, Türkiye. S. 299-304.

Moawad GM, Amin AAH, Hassain AM (1994) Spatial distribution patterns of two cotton bollworns, Pectinophora gossypiella and Earias insulana in Fayoum, Egypt. Ann. Agric. Sci. 39(2): 805-813.

Popescu MA (1990) Population dynamics in Heliothis armigera $\mathrm{Hb}$., Agrotis ipsilon $\mathrm{Hfn}$. and $\mathrm{A}$. segetum Den. et Schiff. as established with a light-trap at Bucarest Baneasa during 1986-1988. Bull. OILB/SROP 13: 44-48.

Qureshi ZA, Ahmed N (1991) Monitoring seasonal population fluctuation of spotted and spiny bollworms by synthetic sex pheromones and its relationship to boll infestation in cotton. J. Appl. Ent. 112: 171-175.

Ünlü L, Kornoşor S (2002) Şanlıurfa ilinde pamukta zarar yapan Earias insulana (Boisd.) (Lep.:Noctuidae) ve Pectinophora gossypiella (Saund.) (Lep.:Gelechiidae)' nın kör kozalardaki bulaşıklık oranlarının belirlenmesi. Atatürk Ün. Ziraat Fak. Dergisi 33(2): 157-161.

Ünlü L, Yücel A, Mamay M (2005) Harran Ovası'nda pamukta zarar yapan pembekurt (Pectinophora gossypiella Saund) ve dikenlikurt (Earias insulana Boisd.)'un ergin populasyon gelişimi. Selçuk Üniversitesi Ziraat Fakültesi Dergisi 19(36): 66-69.

Yabaş MN (1979) Çukurova Bölgesinde Helicoverpa armigera Hbn.'nin biyolojisi üzerinde araştırmalar. Adana Bölge Zirai Mücadele Araştırma Enstitüsü, Doktora Tezi. 201s.

Wilson FD, Wilson RL, George BW (1979) Pink bollworm reduced growth and survival of larvae placed on bolls of cotton race stocks. J. Econ. Entomol. 6: 860-864. 